\title{
Subtitling as a Pedagogical Tool for Language Teaching in Journalism Courses
}

\author{
Lucinéa Marcelino Villela ${ }^{1}$ \\ ${ }^{1}$ Universidade Estadual Paulista, Department of Human Sciences, São Paulo, Brazil \\ Correspondence: Lucinéa Marcelino Villela, Av Eng Luiz Edmundo Carrijo Coube, No. 14-01, \\ 17033-360-Bauru, SP, Brazil. E-mail: lucinea@rocketmail.com
}

Received: August 11, 2014 Accepted: September 12, 2014 Online Published: October 23, 2014

doi:10.5539/elt.v7n11p46 URL: http://dx.doi.org/10.5539/elt.v7n11p46

\begin{abstract}
This study was designed to present and discuss some results produced by a research involving the use of English subtitles of some news videos from the webiste Reuters.com (http://www.reuters.com) with pedagogical reasons in a Brazilian context (Academic English for Journalism). We have developed the research during two semesters at UNESP (Universidade Estadual Paulista Júlio de Mesquita Filho). The professor in charge of the study has chosen the students of Journalism as the audience to whom the videos were presented. The assumptions of many theorists and experts in Audiovisual Translation were adopted as our Theoretical Sources. The first step of the study was the assessment of the syllabus of each course. This was very helpful as a guidance in order to choose the most relevant and interesting videos for students. After the evaluation of academic and professional interests, we chose some videos to insert appropriate subtitles, according to some strategies suggested by Panayota Georgakopoulou and Henrik Gottlieb. Finally we presented the videos during the English classes. At the first time, they were presented without subtitles just to notice the comprehension level of the students. After that, the videos were presented with English subtitles. As we first assumed, the students haven't had the whole comprehension of specific details during the first presentation, they have just used their previous knowledge and the visual aids to help them in a superficial understanding of the news. As the subtitles appear, the process of communication was finally accomplished.
\end{abstract}

Keywords: audiovisual translation, English teaching, Reuters, subtitling, translation studies

\section{Introduction (Note 1)}

The present article proposes a careful analysis of the audiovisual translation tools applied to news videos (Reuters news agency) with pedagogical purposes. We have produced the English subtitles for English Language (EL) disciplines of two undergraduate courses: Journalism and Radio/TV.

The comprehension that the foreign language teaching stands out as an interdisciplinary process that should be carried out in a reflexive, investigative and critical way leads this study to adopt the paradigms of Applied Linguistics and Audiovisual Translation. Our object of study (news videos with intralinguistic subtitles) encompasses two types of linguistic codes: the textual and the oral codes.

According to Frederic Chaume (2004, p. 17),

It is obvious that without the presence of a linguistic code in a text we would not be able to speak of a process of translation properly. It is also true that the linguistic code is a signifying code shared with all texts that can be translated, which means that its analysis is not specific to an audiovisual orientation. However, what singles out the linguistic code in audiovisual texts is that in films, television series, cartoons, and certain advertisements, we are faced with a written text that has to appear oral and spontaneous (written to be spoken as if not written, according to the already classic definition of Gregory and Carroll, 1979).

We highlight that our object of study focused on a handful of news videos in English released on the websites of international agencies (Reuters/US and Reuters/UK) (Note 2). The videos are broadcast in English with no subtitles and the agencies make available the option of a text box that opens on the right side of the videos, so that users can follow up the transcribed audio for the news.

Throughout our academic experience in academic areas such as Journalism and Radio, we have identified the lack of authentic materials related to English video news that could arouse more interest as a class activity in the 
EL teaching. We believe that the use of activities that count on the support of intralinguistic (English $\leftrightarrow$ English) subtitles increase the interest of future professionals, as they can have access to the audio, subtitles and video of international news in real time. The students to whom the pedagogical activities were applied rarely had accessed the Reuteurs videos daily and, as such, positively welcomed the English subtitled materials.

Based on the classification of Araújo (2006, p. 2), two types of concepts were adopted in the pedagogical activities, as follows:

a) Intralinguistic subtitles-Developed in the same language of the broadcast audio. This style is usually employed in news or entertainment programs aimed to enable people with hearing impairment and deafness to grasp the message.

b) Interlinguistic subtitles-Developed when audio news in a foreign language need to be translated to the target audience's native language; in Brazil, movies or programs with English-based audio (or any other foreign language) subtitled to the Portuguese language stand out as clear examples. This type of subtitling process is broadly used in movies theaters, cable TV channels and DVDs.

Hence, having the Journalism undergraduate students as our target audience, the major goal of our research was to assess how the insertion of intra and interlinguistic subtitling may affect the comprehension of news video materials broadcast on the websites of international news agencies.

\section{Literature Review}

The foreign language teaching embraces a wide array of approaches with distinct conceptions regarding the way the teaching-learning process should be carried out.

From the second half of the 1970's onwards, the Communicative Approach started being employed as a concept that highlighted both the sense and the meaning, thus proposing interactions among the subjects involved in the teaching process (learners and teachers).

In a book published in the beginning of the 1990's, Dimensões comunicativas no ensino de linguas, the Brazilian researcher José Carlos de Almeida Filho (2002) aroused several discussions in the academic community and raised a flag toward more interactive language teaching approaches than the other approaches defended by previous methodologies. One of his concepts was (Note 3),

O ensino comunicativo é aquele que organiza as experiências de aprender em termos de atividades relevantes/tarefas de real interesse e/ou necessidade do aluno para que ele se capacite a usar a língua-alvo para realizar ações de verdade na interação com outros falantes-usuários dessa língua (Almeida Filho, 2002, p. 36, emphasis added).

Two issues pointed out by Almeida Filho should be emphasized, the employment of relevant, real interest activities that are concurrently necessary to the student.

In order to successfully put together activities or tasks deemed to be of real interest and that fulfill the expectations of the students, a previous assessment of their perspectives, desires and needs regarding the EL teaching should be taken into account. However, the reality of the Brazilian academic syllabus, stemming both from the lack of dialogue among departments and from on-demand alterations of syllabuses, generates update processes that can take up to a decade to occur.

These discrepancies hold the teachers even more accountable for a more effective dialogue with the learners. Such exchange process between both sides provides teachers with possibilities of getting information on the professional fields the students plan to act on. With that in mind, according to Almeida Filho (2002, p. 36), the teachers will then focus their teaching activities on "tasks of real interest for the student".

As we consider the English Language Teaching for Specific Purposes guidelines to be adequate for the establishment of syllabuses that meet the needs of the learner, as those in Journalism area, our theoretical conception will be grounded on the works of Hutchinson and Waters (1987), Strevens (1988), Robinson (1991), Dudley-Evans and St John (1998), Wright (1992), as well as the Brazilian researchers Celani (1988), and Ramos (2005).

In his article The Benefits of ESP, researcher Wright (1992) defines the English Language for Specific Purposes as a "language learning which has its focus on all aspects of language pertaining to a particular field of human activity, while taking into account the time constraints imposed by learners".

According to the absolute characteristics of the Language Teaching for Specific Purposes presented by Dudley-Evans and St John (1998, p. 3), ESP is 
1) Designed to meet specific needs of the learners;

2) Related in content (that is in its themes and topics) to particular disciplines, occupations and activities;

3) Centered on the language appropriate to these activities in terms of grammar, lexis, discourse, semantics and so on, and analysis of discourse.

Taking into account the academic context of the English Language teaching for the Journalism area, we deem the adoption of a few of the above-mentioned characteristics to be quite pertinent, aiming to constantly address the learners' contents and areas of interest.

We understand, for instance, that the expectations of Journalism undergraduate students go beyond reading and understanding EL texts in foreign newspapers and websites of international news agencies; they also need to focus on oral production and comprehension, as well as to develop translations/versions of specific portions of texts that can be inserted into the stories written in their native language.

Bearing that in mind, we aim to adopt and apply the knowledge produced in two of our areas of interest, English Teaching for Specific Purposes and Audiovisual Translation.

The theoretical concepts of the translation studies deem the translator to be that type of professional who is actively present in the text to be translated. Therefore, we consider the translating task as a constant production of meanings. According to Arrojo's (1992, pp. 103-104) definition (Note 4),

Aprender a traduzir, tornar-se tradutor, implica, portanto, em primeiro lugar, reconhecer seu papel essencialmente ativo de produtor de significados e de representante e intérprete do autor e dos textos que traduz [emphasis added].

Another source of our paradigms of the translation and textual interpretation fields is the post-structuralist view of translation developed by authors such as Derrida (2000, 2002), Fish (1980), Arrojo (1986, 1992, 1993), Rajagopalan (1992, 2000), Ottoni (2000) and Venuti (2002).

Venuti (2002, p. 92) (Note 5) sums up the theoretical conception of the "scandalous translation" as an activity that renders obedience to the original (foreign) text and the domestic culture. Nonetheless, the author does not advocate a disdain to the original text, as complained by several post-structuralism critics; he actually underlines the responsibility translators have of standing up for cultural communities. According to the author (Note 6),

[...] a tradução é escandalosa, visto que ela cruza as fronteiras institucionais: a tradução não somente requer pesquisa erudita para trafegar entre as linguas, culturas e disciplinas, mas ela obriga o erudito a considerar as comunidades além da academia [...]

An adequate translating practice is achieved only when the learning process harmonizes translating competences and the theoretical knowledge of the activity. Hence, the efficient translation is considered a combination of the development of linguistic and technical competences (deepened lexical and semantic knowledge of both languages; use of different lexical tools) and the knowledge of contemporary translation theories. Clarifications on genre, text types and their specificities should also be expected.

Given our specific interest - the audiovisual translation by means of the insertion of subtitles into materials made available by websites of international news agencies - we carried out a bibliographic survey comprised of theses, academic works, dissertations and articles produced by some researchers of the State University of Ceará and the Pontifical Catholic University of Rio de Janeiro (PUC-RJ), who have devoted themselves to the study of subtitling processes in several different contexts.

Part of the researchers studies the insertion of subtitles into the EL teaching inside public and private schools contexts; others assess intralinguistic subtitling processes (Portuguese $\leftrightarrow$ Portuguese) in TV programs (news, sports, education, and entertainment), whose target audience might be composed of deaf and hearing impaired people.

The researcher Vera Lúcia Santiago Araújo, a Brazilian pioneer in these studies, has a comprehensive set of publications in this field and provides orientation and guidance for various subtitling research groups in several levels. Araújo's paper, O Processo de Legendagem no Brasil' (2006) brings pedagogical guidelines to translators and foreign language teachers interested in learning the techniques and specificities of the subtitling activity.

Similarly to Lina Alvarenga, Araújo (2006) differentiates the work of the subtitle subtitlers and the captioners. The first professionals are the creators of the subtitles, professionals with a deep knowledge of the languages to be dealt with and profoundly aware of the needs and difficulties involved in such process. The latter, on their turn, are those who "record" and/or release the subtitles by means of translation softwares. They are handed the 
ready subtitles and are not responsible for the adaptation of the texts to the needs of the viewers.

Our major interest throughout this present research was to assess the work of the subtitler, as we focus on the needs of the EL learner watching a news video with inter and intralinguistic subtitles.

Another issue raised by several authors who address this thematic is referred to the authenticity offered by intralinguistic subtitled materials to the teaching-learning environment. This feature is extremely appropriate within the EL teaching context for Journalism undergraduate students who deal with the elaboration and comprehension of "facts" obviously related to reality and authenticity since the outset of their academic education.

Some studies showed that the audio description, another type of audiovisual translation, is also employed as a support tool in foreign language teaching for specific purposes. In the international event "Media for All 5th: audiovisual translation: Expanding Borders" (2013), researchers Noa Talaván and Jennifer Lertola presented their work 'Audiodescription and foreign language education: new approaches'. In that event, they had the opportunity to report on their teaching experiences in English for Specific Purposes courses (Level 1) tailor-made for the tourism area. Their students produced audio descriptions for advertisement videos focused on international tourism and these activities addressed the production of oral procedures proposed by the above-mentioned course.

\section{Discussion}

The main proposition of this article derives from the previous experiences the researcher (English Professor) had in using news videos made available on the Reuters website. Among the various subjects already addressed in the classroom are the scandals involving the former IMF Managing Director, Strauss-Kahn (2011); the release of Steve Jobs' biography (2011); tattoo and body art (2012); the fire in the Santa Maria night club (2013); the rapes in India (2013) etc.

The class activities employing subtitled videos always take place in a two-phase process. First, the researcher-professor makes a brief introduction of the theme and students watch the video with no subtitles.

Next, the teacher promotes a short discussion on the information presented by the video. In this phase, it can be observed that several pieces of information addressed by the students are quite inaccurate due to the natural speech of both the reporters and the interviewees, several of them non-native speakers of the language.

In one of those experiences, Journalism undergraduate students showed plenty of difficulties keeping pace with the EL video and audio, as well as in follow-up questions related to the release of Dominique Strauss-Kahn from house arrest in June 2012. We observed that their main difficulty was actually not related to the surrounding technical apparatus (speakers, projectors etc), but to the fast-track speech of the interviewees (native and non-native) and the narrative of the journalists. As the same video was presented again, now with intralinguistic subtitles (English $\leftrightarrow$ English), there was quite an improvement in their comprehension, in spite of the absence of the necessary subsidies on the international political context (IMF, presidential elections in France, etc).

We used the Subtitle Workshop software to create the subtitles. A previous knowledge of the subtitling process and its techniques and characteristics is demanded for its operation.

We pay particular attention to the maintenance of the maximum limit of 32-35 characters per subtitle line and to the separation of one subtitle from the other, thus perfectly matching imagery and audio (narration and testimonies). This work demands a careful review of line and subtitle timing and synchrony, as the videos are usually composed of various testimonies and imagery under the format of video clips.

Our last example of the pedagogical use of this approach came from a story broadcast by Reuters UK. In May 2013, a British soldier was brutally murdered in Woolwich. In that occasion, the British press built up an overstated sensationalism by broadcasting shocking pictures and images of the murder exhibiting the blood-covered knife used in the crime. Aiming to discuss the "journalistic ethics" theme, we used the Reuters video with intralinguistic subtitles that covered the story on May 23rd, 2013.

After playing the video with subtitles twice, students were comfortable to carry out the proposed textual interpretation activities on ethics and journalistic sensationalism. 


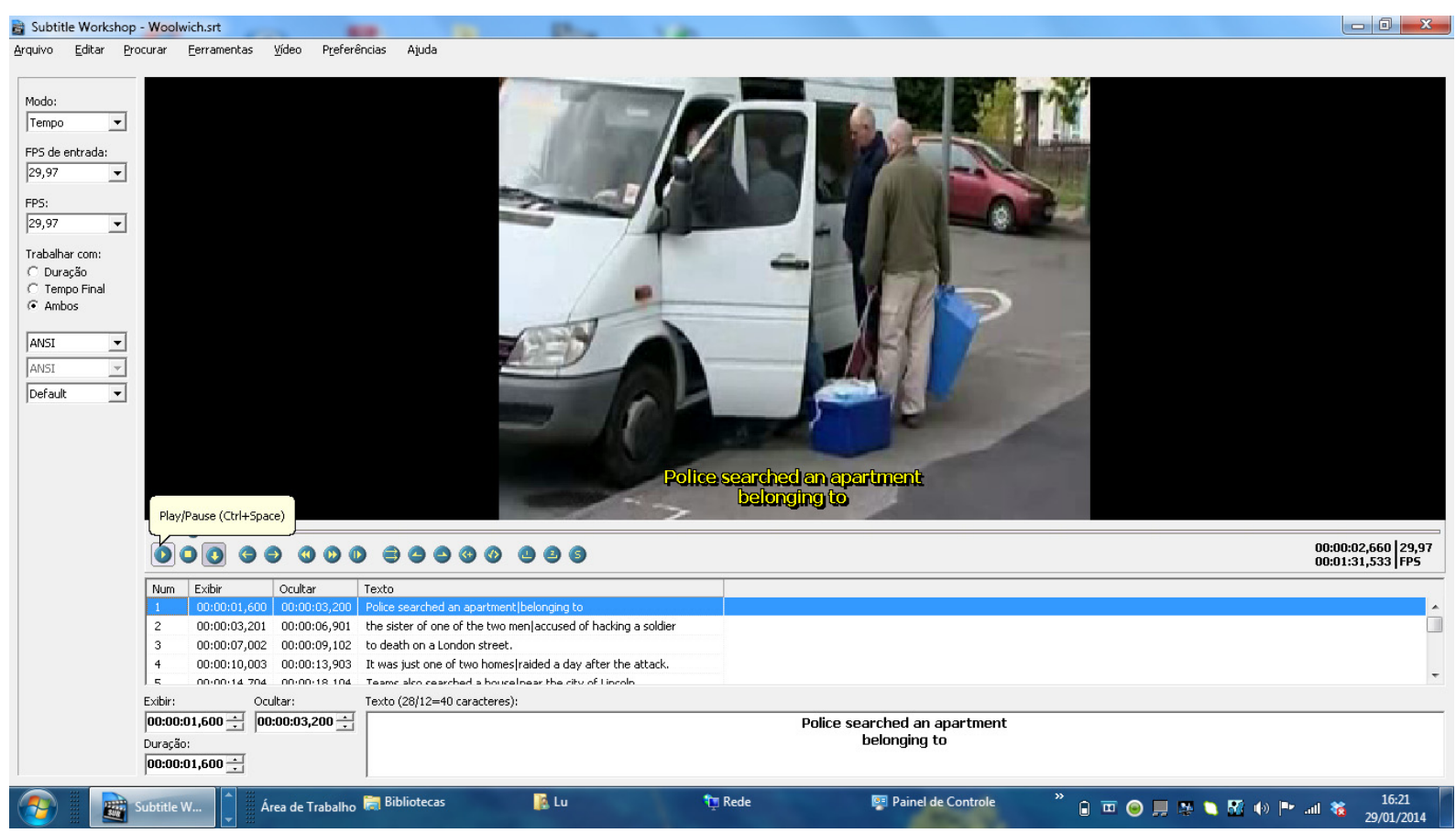

Figure 1. Example of the process of inserting subtitles for Reuters videos using Subtitle Workshop (http://uk.reuters.com/)

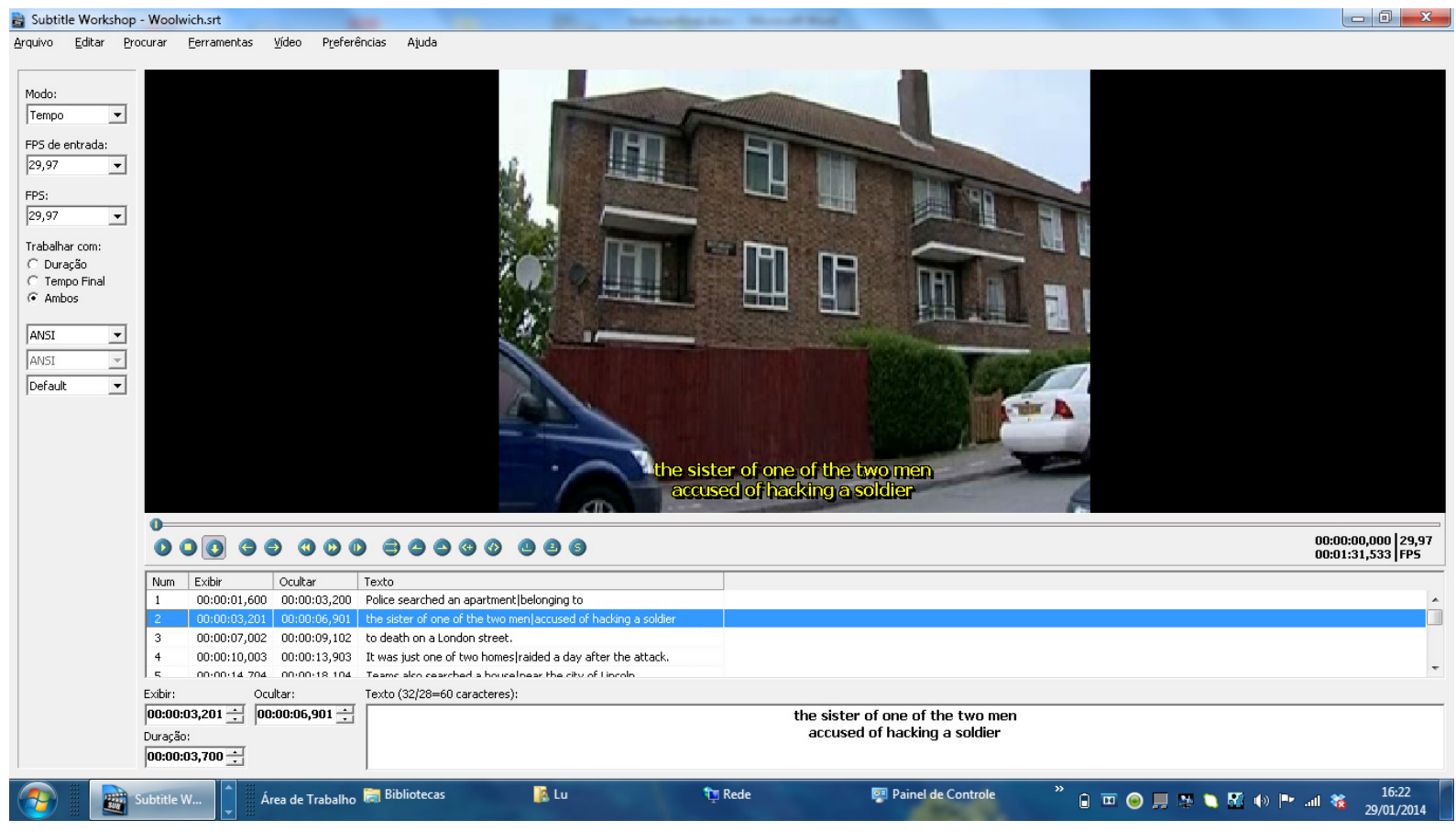

Figure 2. Example of the process of inserting subtitles for Reuters videos using Subtitle Workshop (http://uk.reuters.com/) 


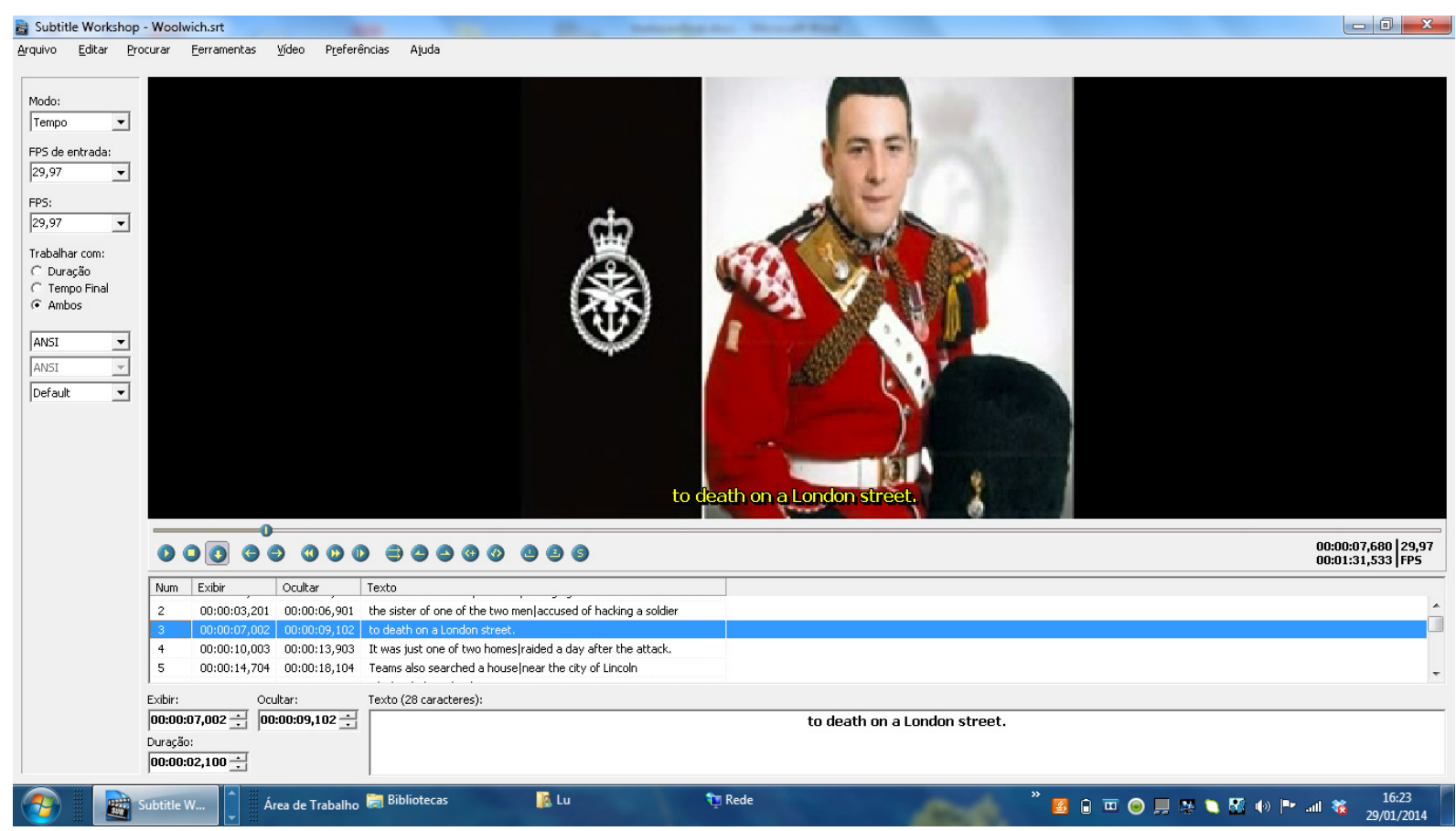

Figure 3. Example of the process of inserting subtitles for Reuters videos using Subtitle Workshop (http://uk.reuters.com/)

We deem the subtitling practice to be a tool that brings about several pedagogical benefits to English Language learners, as it enables a more efficient comprehension of the audiovisual content presented in the classroom. As any other resource, however, it should not be employed in isolation. It should be contextualized and be presented as part of a broader process also composed of texts, audiovisual materials and the oral and written practice of the foreign language.

\section{References}

Almeida Filho, J. C. P. (2002). Dimensões Comunicativas no ensino de línguas. Campinas: Pontes.

Araújo, V. L. S. (2006). O processo de legendagem no Brasil. Revista do GELNE, 1(2), 156-159.

Arrojo, R. (1992). O signo desconstruído: implicações para a tradução, a leitura e o ensino. Campinas: Pontes Editores.

Chaume, F. (2004). Film Studies and Translation Studies: Two Disciplines at Stake in Audiovisual Translation. Meta, 49(1), 12-24. http://dx.doi.org/10.7202/009016ar

Dudley-Evans, T., \& St John, M. J. (1998). Developments in English for Specific Purposes: A multi-disciplinary approach. Cambridge: Cambridge University Press.

Lertola, J., \& Talaván, N. (2013). Audiodescription and foreign language education: New approaches. Paper presented at 5th International Conference Media for all: Audiovisual translation: Expanding Borders (Palace Hotel Dubrovnik, 25-27 September, 2013).

Venuti, L. (1998). The Scandals of Translation. London: Routledge.

Venuti, L. (2002). Escândalos da Tradução (V. Lucinéa, E. Marileide \& B. Valeria, Trans.). Bauru: EDUSC.

Wright, C. (2001). The benefits of ESP. Retrieved from http://www.camlang.com/art001.htm

\section{Notes}

Note 1. The author of this paper decided to insert the quotations in their original language, therefore when quotations by Brazilian authors are mentioned she presented the translations on endnotes.

Note 2. Our choice for the Reuters News websites (American and British) resulted from the fact that these agencies make the transcription of their news videos available, a function that is not provided by other news 
agencies. Such transcriptions will work as a source text toward the elaboration of intra and interlinguistic subtitles.

Note 3. The communicative teaching is known as a process that organizes the learning experiences according to the relevant activities/real interest tasks and/or student's needs, so that the student is empowered to make use of the target language while performing real actions during his interaction with other speakers-users of that language [my translation, emphasis added].

Note 4. Learning how to translate, becoming a translator, therefore, primarily implies the recognition of our essentially active role in the production of meanings, a role of a representative and interpreter of the author and the translated texts [my translation, emphasis added].

Note 5. The book The Scandals of Translation by Lawrence Venuti was translated by me and some researchers from Brazil, it has been published in 2002 for EDUSC publishing house.

Note 6. Translation is scandalous because it crosses institutional boundaries: not only does translation require scholarly research to move between languages, cultures, and disciplines, but it compels the scholar to consider constituencies beyond the academy (Venuti, 1998, p. 46).

\section{Copyrights}

Copyright for this article is retained by the author(s), with first publication rights granted to the journal.

This is an open-access article distributed under the terms and conditions of the Creative Commons Attribution license (http://creativecommons.org/licenses/by/3.0/). 